\title{
Poverty, Welfare and Income Distribution Implications of Reducing Trade Costs Through Deep Integration in Eastern and Southern Africa
}

\author{
Edward J. Balistreri' ${ }^{a}$ Maryla Maliszewskab, \\ Israel Osorio-Rodarte ${ }^{b}$, David G. Tarr ${ }^{b}$, \\ and Hidemichi Yonezawa ${ }^{\text {c,* }}$
}

${ }^{a}$ lowa State University, Ames, IA 50011-1054, USA, 'b The World Bank, Washington, DC 20433, USA, and ${ }^{\mathrm{C}}$ ETH Zurich, 8092 Zurich, Zurich, Switzerland

*Corresponding author: David Tarr, 7901 Hispanola Ave., Unit 1102, North Bay Village, FL 33141, USA.

Email: gtarr@gmail.com.

\begin{abstract}
We examine regional and unilateral policies to reduce three kinds of trade costs in Eastern and Southern Africa. Our article is the first CGE-microsimulation model to assess the impacts of the reduction of trade costs on poverty and income of the poorest $40 \%$ of the population. We estimate significant reductions in the poverty headcount and increases in income for the poorest $40 \%$. We find that trade facilitation would increase the 'share' of income of the poorest $40 \%$ of the population, however, services reform decreases the share. We find and explain why our three types of trade costs have very diverse impacts across the countries.
\end{abstract}

Key words: poverty, income distribution, microsimulation, Tripartite free trade agreement, deep integration, computable general equilibrium

JEL classification: F14, F15, F17, 055, F55

\section{Introduction}

Trade costs are a much more important barrier to trade integration than tariffs in most sub-Saharan African countries. ${ }^{1}$ Further, unlike tariffs, which generate revenue for the

1 Arvis et al. (2016) found that trade costs decline in the level of income of the country, but SubSaharan and low income countries remain subject to very high trade costs. The World Economic Forum (2012) found that it is still considerably more expensive to trade with Africa than with other regions, and, in many cases, the cost of trading is a more important obstacle to trade development 
importing country, trade costs often impose real resource costs on both importing and exporting countries. Thus, the expected gains from reducing trade costs are greater than for the 'equivalent' tariff, which partly motivates the conclusion of Schiff and Winters (2003) that the real gains from regional trade initiatives come from deep integration.

As part of their efforts to raise incomes and reduce poverty, countries in Eastern and Southern Africa are attempting to address their high trade costs through deep integration in their regional initiatives. Notably, the proposed 26 country Tripartite Free Trade Area

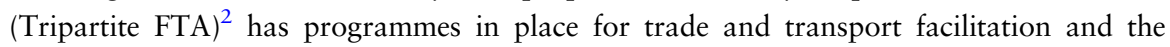
reduction of non-tariff barriers, and has the objective in 'Phase II' to liberalise trade in services. ${ }^{3}$ In addition, the members of the East African Customs Union (EACU) also have initiatives within the EACU to reduce trade costs. ${ }^{4}$ In order to assess the relative gains of narrowing or widening the reforms, we assess the impacts on overall welfare. poverty and the incomes of the poorest $40 \%$ of the population (sometimes referred to here as income distribution effects) of comparable reforms by the members of the EACU applied only within the EACU, more widely in the Tripartite FTA and unilaterally by the EACU to all countries in the world, where feasible.

We decompose trade costs into three categories: time in trade costs that can be lowered by trade facilitation; non-tariff barriers; and the costs of business services. ${ }^{5}$ In order to analyze the impacts of the change in these trade costs on poverty and welfare, we combine two models: a global computable general equilibrium (CGE) model with imperfect competition and foreign direct investment in services and a microsimulation model. The microsimulation model uses estimates from our global CGE model as inputs into the microsimulation analysis. Although it is a 'top down' or sequential approach to poverty and income distribution analysis of macro shocks, we assure consistency between the two models in the aggregate results and in key aspects of the construction of the datasets.

than trade policies. Brenton and Isik (2012) have also documented the high costs of trading in subSaharan Africa. See also, the estimates of Hummels et al. (2007) and Minor (2013) that show the trade facilitation costs alone (what they call the 'time in trade' costs) are greater than tariffs as an obstacle to trade for most countries.

2 The Tripartite FTA is the union of three regional trade groups: the East African Customs Union (EACU); the Common Market of East and Southern Africa (COMESA); and South African Development Community (SADC).

3 See https://www.tralac.org/news/article/11860-the-tripartite-free-trade-area-a-breakthrough-in-july2017-as-south-africa-signs-the-tripartite-agreement.html and https:/www.ictsd.org/bridges-news/ bridges-africa/news/the-tripartite-free-trade-area-agreement-a-milestone-for-africa $\%$ E2\%80\%99s. Accessed August 17, 2017.

4 See East African Community (2012), East African Community Secretariat (2011) and World Bank (2012).

5 The econometric results of Arvis et al. (2016) support our decomposition of trade costs. Arvis et al. found that the following measures stand out as important drivers of trade costs: (1) transport connectivity and trade facilitation; and (2) 'behind the border' regulatory and institutional measures. They explicitly identify trade facilitation. Regarding business services, transport connectivity is part of business services; and other business services that impact trade costs, such as telecommunications, banking and insurance, are influenced strongly by behind the border measures. Regarding non-tariff barriers, Cadot and Gourdon (2014) have shown that the principal non-tariff barriers are regulations of product standards. 
Despite the expected larger impacts of the reduction in trade costs compared with tariffs, our article is the first CGE-microsimulation model to examine the impacts of the reduction in trade costs on poverty from either unilateral, multilateral or regional liberalisation; ${ }^{6}$ and it is one of the few to examine any aspect of the poverty impacts of regional integration. Of the almost 60 studies surveyed by Teichman (2016) that combine a CGE model with a microsimulation model for poverty analysis, none examine the consequences of the reduction in trade costs; and only two examine the poverty impacts of regional trade agreements. These two studies, Bussolo et al. (2008) for four Latin American countries and Boysen and Matthews (2016) for Uganda, examine tariff reductions only and employ CGE models with perfect competition and no foreign direct investment. They find small or no gains from the preferential trade agreement so little poverty impact. ${ }^{7}$ Although they do not contain microsimulation models to assess poverty impacts, Karingi and Fekadu (2009), Jensen and Sandry (2011) and Willenbockel (2013) have executed general equilibrium assessments of the impacts of the Tripartite FTA. They focus either exclusively or primarily on preferential tariff reductions at the aggregate level. ${ }^{8}$ They find small welfare changes from preferential tariff reduction in the Tripartite FTA, with many countries losing and net gains of only about $0.1-0.2 \%$ of GDP. Our estimates of the impact of tariff changes are consistent with these earlier studies as well as the new gravity approach to modelling the impacts of changes in trade costs ${ }^{9}$ - there are little gains with some countries losing. Depending on the country or region, however, our estimates of the gains from reductions

6 Some CGE studies have examined the impact of trade costs, or some of aspects of trade costs, without a poverty or distribution assessment, including Balistreri et al. (2015a), Maliszewska et al. (2009) and Jensen and Tarr (2012).

7 Boysen and Matthews find losses for Uganda of $0.03 \%$, while Bussolo et al. (2008) find that the gains for their four countries range from 0.09 to $0.39 \%$ of consumption. An additional CGEmicrosimulation study of tariff reductions in regional trade agreements with a model of perfect competition is Bussolo and Niimi (2009). They examine preferential tariff reductions in Nicaragua and estimate gains between 0.5 and $1.1 \%$ in real GDP.

8 Jensen and Sandry add a 2\% uniform reduction in non-tariff barriers on goods and cross-border services to preferential tariff reduction. Willenbockel (2013) also executes a scenario with a $5 \%$ reduction in border crossing costs for all goods based on unpublished TradeMark South Africa estimates of border crossing costs; then the estimated gains increase to $0.4 \%$ of GDP for the Tripartite FTA in aggregate. Latorre (2016) has conducted an interesting analysis of the impact of FDI and tariff reform on male versus female wages in Tanzania. Although they do not focus on Eastern or Southern Africa, two other interesting general equilibrium assessments of trade policy changes in Africa are the following. Anderson et al. (2006) find that global free merchandise trade would boost real incomes in subSaharan Africa more than proportionately than in other developing countries; but partial liberalisation proposals would capture only a small share of the gains. Mevel and Karingi (2012) analyze the removal of all tariffs on goods within the African continent as a whole. They find this would increase intraAfrican trade by $52 \%$, but if trade facilitation measures are also implemented that reduce the time costs of trade by $50 \%$, intra-African trade would more than double.

9 Two recent gravity based approaches to an assessment of the gains from preferential trade agreements (PTAs) are Caliendo and Parro (2015) and Caliendo et al. (2015). Caliendo and Parro (2015) use a Ricardian model to estimate the impacts of NAFTA. They estimate that Mexico would gain $1.3 \%$ of welfare, but only very small welfare impacts on the United States and Canada. Caliendo et al. (2015) find that the welfare impact of PTAs has been very small, at about $0.3 \%$. Our results confirm the reasoning of Limão (2016) who indicates that he believes that the small estimates of 
of trade costs within the Tripartite area are about 10-30 times larger than their estimated gains of preferential tariff reduction, with significant reductions in poverty-suggesting very different stakes.

The CGE model contains 18 sectors and Kenya, Tanzania, Uganda, Rwanda, ${ }^{10}$ COMESA, SADC, the US, EU, China and rest of the world as regions. Balistreri et al. (2015b), hereafter BTY (2015b), assessed the near-term impacts of reducing trade costs in Eastern and Southern Africa with a comparative static CGE model, but did not assess poverty or distributional impacts. In this article, we extend the comparative static model of BTY (2015b) to a comparative steady-state model to derive estimated impacts for 2030 and link the CGE model to a microsimulation model.

An important database for our poverty and income distribution results is the time in trade costs (or trade facilitation) database of Hummels et al. (2007), Hummels and Schaur (2013) and Minor (2013). A central finding of the studies is that the ad valorem equivalents (AVEs) of time in trade costs vary across products. Our more accurate database has relatively higher time in trade costs for agriculture. As agriculture is unskilled labour intensive in our African countries, our results show that the poor tend to benefit more than proportionately from trade facilitation.

Our model contains foreign direct investment as well as cross-border trade in services, which allow us to assess the poverty impacts of liberalisation of barriers against foreign services suppliers. We show that services liberalisation contributes significantly to the reduction of poverty in our African regions. Due to the relatively intensive use of skilled labour in business services, however, we find that the share of income going to the poorest $40 \%$ of the population declines.

Our decomposition analysis reveals that the estimated aggregate gains and poverty impacts vary considerably across countries and depend on the reform. Thus, the regions and countries have very different stakes in the various reforms and would have an interest in negotiating for different reforms in different agreements. Notable examples are the following. In the regional agreements, trade facilitation tends to dominate in relative importance, but is especially important for Uganda as a share of its gains. In the Tripartite FTA, Kenya gains the most from the reduction of non-tariff barriers on its exports to partner countries in goods as well as from improved market access for its insurance companies in COMESA. Global services liberalisation leads to very large estimated gains for Kenya, Uganda and especially Rwanda from better access to services. Tanzania gains the most from liberalisation of its own high non-tariff barriers when liberalised widely. COMESA, in the Tripartite FTA, gains the most from liberalisation of its own high services barriers.

The article is conceptually innovative in several ways. As mentioned, it is the first to examine the poverty and income distribution impacts of the reduction in trade costs. It employs a model that includes imperfect competition and foreign direct investment that is necessary for the effective assessment of the poverty effects of services liberalisation. It is the first microsimulation exercise to employ the time in trade costs database differentiated by product, which we show has important poverty implications. In addition, we adapt the

Caliendo and Parro (2015) and Caliendo et al. (2015) are explained by the fact that these studies only consider the tariff impacts of the PTAs.

10 Due to lack of data, Burundi, the fifth member of the EAC, is not represented as a separate region of our model. 
comparative steady-state model employed by several authors to eliminate its well-known upward bias in its welfare estimate. Finally, our decomposition analysis of the various policy choices and their components allows us to infer their relative importance on poverty and income of the poorest $40 \%$ of the population for our different African regions.

We organise the article as follows. In Section 2, we provide an overview of the CGE and the microsimulation models. In Section 3, we explain the data. The CGE model results are presented in Section 4 and the microsimulation results for poverty and income impacts on the poorest $40 \%$ of the population are presented in Section 5. In Section 6, we conclude with a summary of the key results and the stakes of the regions of our model based on the reform.

\section{Overview of the CGE and Global Income Distribution Dynamics Models}

\subsection{Introduction}

In this article, we obtain results for poverty and income distribution in several African countries of deep integration in East and Southern Africa. We do this by first assessing the impacts on the variables that impact poverty and income distribution in a multiregion comparative steady-state CGE trade model focusing on Eastern and Southern Africa, and linking it to a microsimulation household model. The key variables on which we obtain CGE estimates are the change in the value of real consumption, the change in real wages of skilled and unskilled labour in agriculture and non-agricultural sectors and the change in prices of food and non-food items. We then use those estimates as inputs in the Global Income Distribution Dynamics (GIDD) microsimulation model to obtain assessments of the changes in the poverty headcount and income of the poorest $40 \%$ of the population.

Our article employs an innovative version of a comparative steady-state model to assess impacts in the year 2030. We extend the comparative static version of the CGE model in BTY (2015b). ${ }^{11}$ For the comparative steady-state model, we employ exogenous labour force projections and endogenously determine the capital stock for 2030. Innovatively, as explained in Section 2.2 below, we also endogenously adjust investment to eliminate the well-known bias in the welfare assessment of the comparative steady-state model. Otherwise, the comparative steady-state model is the same as the comparative static model. For a detailed description of the comparative static version of our model, we refer the reader to BTY (2015b). Here we provide a brief overview.

There are 18 sectors in the model shown in Table 1. There are three categories of sectors: (1) four perfectly competitive goods and services sectors; (2) seven imperfectly competitive goods sectors; and (3) seven services sectors in which there is imperfect competition and foreign direct investment. Imperfectly competitive firms have a fixed cost and constant marginal costs with respect to output. Regardless of sector, all firms minimise the cost of production.

Primary factors are skilled labour, unskilled labour, capital (including land) ${ }^{12}$ and natural resources. Regarding capital, there is mobile capital and sector-specific capital in imperfectly competitive goods sectors and services sectors with FDI; and primary inputs imported by

11 That model builds on the algebraic structure of the small open economy models of Balistreri et al. (2009), Jensen and Tarr (2012), Jensen et al. (2010) and Balistreri et al. (2009; 2015a).

12 Given the nature of the shocks we consider (which are economy-wide), we do not believe the aggregation of capital and land has a significant impact on the results. 
Table 1: List of Sectors, Regions and Factors of Production in the Eastern and Southern Africa Model

\begin{tabular}{ll}
\hline Business services with FDI & Dixit-Stigliz goods \\
Air transport & Chemicals mineral and metal products \\
Communication & Energy and minerals \\
Insurance & Food products \\
Business services nec & Petroleum and coal products \\
Financial services nec & Other manufacturing \\
Transport nec & Textiles, apparel and leather products \\
Water transport & Wood and paper products \\
CRTS goods and services & Regions \\
Agriculture and forestry & Kenya \\
Other services & Tanzania \\
Trade & Uganda \\
Utilities & Rwanda \\
& COMESA \\
Factors of production & SADC \\
Skilled labour & USA \\
Unskilled labour & European Union (EUR) \\
Capital & China \\
Natural resources & Rest of the World (ROW) \\
\hline
\end{tabular}

multinational service providers, reflecting specialised management expertise or technology of the firm. There is some sector-specific capital for each imperfectly competitive firm (and for firms in services sectors with FDI) for each region of the model. In the sectors where there is sector-specific capital, there are decreasing returns to scale in the use of the mobile factors and supply curves in these sectors slope up. Sector-specific factors help to guarantee the existence of an equilibrium and avoid an unrealistic concentration of output in a narrow group of sectors. One extension of BTY is that we allow sector-specific labour. In our benchmark equilibrium, we assume that $50 \%$ of labour is sector specific (both skilled labour and unskilled labour). Since we need an agricultural wage and a non-agricultural wage for the microsimulation model, we added sector-specific labour to produce a wage rate that differs by sector. Value-added is an aggregate of our primary factors with elasticity of substitution $\sigma$. Skilled (and unskilled) labour is an aggregate of sector specific and mobile labour with elasticity of substitution $2 \sigma$. Thus, the share of sector-specific labour may change in a counterfactual scenario, including a comparative steady-state scenario.

\subsection{Comparative steady-state formulation for the 2030 solution of the model}

\subsubsection{Basic theory of the endogenous capital stock in the comparative steady-state model}

In the comparative static model, we assume that the capital stock is fixed and the rental rate on capital is endogenously determined. In the comparative steady-state model, the logic is reversed: the real return on capital is fixed, but we allow the capital stock to adjust to its steady-state equilibrium along with of the model features we employ in our comparative static model. The comparative steady-state model assumes that investors demand a given real rate of return on capital in order to invest in a given country. We assume that the rate of return demanded by investors for each country or region is initially in long run equilibrium. If a trade policy or other 
type of shock happens to induce and increase in the rate of return on capital so that it exceeds the initial rate of return, investors will invest and expand the capital stock. Expansion of the capital stock drives down the marginal product of capital, i.e., it drives down the rental rate on capital. A new equilibrium in the comparative steady-state model is determined when the capital stock rises sufficiently that the real rate of return on capital falls back to the initial level. ${ }^{13}$

To analyze trade policy, this comparative steady-state approach has been employed by many authors, including Harrison et al. (1996, 1997a, 1997b), Baldwin et al. (1999) and Francois et al. (1996). The approach, however, dates to the 1970s.

\subsubsection{Adjustment to eliminate the bias in the welfare calculation in the comparative steady-state model}

The approach employed in the above studies ignores the foregone consumption necessary to achieve the higher level of investment, and, thus, is biased upward regarding the estimated welfare gains within the framework of the model assumptions. We have made an important extension in the modelling approach of the above studies to adjust for the upward bias in the estimated welfare gains. ${ }^{14}$ In a discrete time intertemporal model, the capital stock in period $t$ is as follows:

$$
K(t)=K(t-1) d+I(t-1)
$$

where $K(t)$ and $I(t)$ are the capital stock and investment in period $t$, respectively, and $d$ is one minus the depreciation rate. Since the capital stock in period $t$ is the cumulative undepreciated value of investments over time, if we assume that investment in each period is constant equal to $I$, then:

$$
K(t)=I *\left[\left(1-d^{t}\right) /(1-d)\right]
$$

It follows that for a fixed time period and depreciation rate, the percentage change in the constant value of investment in each period is equal to the percentage change in the capital stock, i.e.,

$$
\Delta K / K=\Delta I / I
$$

Following equation 3, in our comparative steady-state model, we assume that investment increases in proportion to the increase in the capital stock. We measure welfare change from Hicksian equivalent variation, which is based on consumption only. Thus, when the capital stock increases in our model, investment will also increase, thereby reducing the reported welfare gains. This adjustment removes the well-known upward bias in comparative steady-state models from ignoring the investment costs of increasing the capital stock. To assess the importance of this adjustment, we also execute the model without the investment adjustment. We see that the adjustment is important. In the case of our Tripartite scenario, the estimated gains without removing the bias are from $17 \%$ higher (for COMESA) to $70 \%$ higher in the case of Tanzania.

13 The rate of return on investment in our model is the rental rate on capital divided by the cost of a unit of the capital good. We allow both mobile and sector-specific capital to be endogenously determined in the comparative steady-state model.

14 This approach was first suggested in an unpublished paper by Francois et al. (2013). 
If the shock favours labour-intensive sectors and the relative return to capital falls sufficiently, it could induce a decline in the capital stock. We have imposed a lower bound of zero, however, on the change in the capital stock in any of our scenarios, assuming that over a 15 -year period it is not reasonable to allow a decline in the capital stock in our regions. If the lower bound constraint is binding, the real return on capital will decline in the new steady-state equilibrium. The lower bound is never binding in any of the scenarios reported in this article. ${ }^{15}$

\subsubsection{Labour force projections for 2030}

In Section 3.5, we discuss data for projections of the labour force (both skilled and unskilled labour) as well as the total population for 2030. Based on these data, in all of our scenarios for 2030, we shock the initial labour force data such that the labour force for the 2030 scenarios in the African regions of the model satisfies two properties. First, the percentage increase in the total labour force of our model increases by the percentage increase in the total labour force from the projected labour force data. Second, the percentage point change in the skilled labour force versus unskilled labour force in our model is the same as in the projected labour force data. The labour force increase has the impact of increasing the marginal product of capital. If the population increases, however, we would expect an approximately proportional decrease in per capita real consumption. To avoid a biased overestimate of the welfare gain in our comparative steady-state model with labour force growth, we reduce the welfare gain estimate (Hicksian equivalent variation of the representative agent) by the percentage increase in the population. ${ }^{16}$ That is, suppose the population in 2030 is $z$ times the population in our initial equilibrium. If EV is our solution for Hicksian equivalent variation in our steady-state model, then our measure of the change in welfare in our steady-state model is $\Delta W$, where $\Delta W$ is defined by the following equation:

$$
\Delta \mathrm{W}=\mathrm{EV} / z
$$

\subsection{Microsimulation methodology for poverty and income distribution results}

To estimate distributional effects, we use the microsimulation model known as the GIDD. Bussolo et al. (2010) originally developed the GIDD, building on the work of Bourguignon et al. (2008) and Davies (2009). The GIDD has been applied in several examples including Devarajan et al. (2015) and others that are discussed in Bourguignon and Bussolo (2013). Here we provide an intuitive explanation. For a full mathematical explanation of the GIDD, we refer the reader to Balistreri et al. (2016).

15 The capital stock lower bound is binding for Uganda in a scenario where we consider tariff reduction in the Tripartite region. This reform strongly favours Ugandan agricultural exports, which are highly labour intensive, inducing a decline in the real return on capital. Given our lower bound constraint on the change in the capital stock, equilibrium requires a decline in the real return on capital (analogous to the comparative static model).

16 In many of our African countries the percentage increase in the labour force exceeds the percentage increase in the population. A greater share of the population in the labour force should increase welfare, so we reduce the estimated welfare by the percentage increase in the population, not the percentage increase in the labour force. 
For inputs, the GIDD uses CGE model estimates of the changes in four differentiated wages: for skilled, unskilled, agricultural and non-agricultural labour and changes in the prices of agricultural and non-agricultural goods. We impose consistency between the GIDD and the CGE models in two ways. First, as explained in Section 2.2.3, in both models we use the same projections in aggregate population and education (skill) structures for 2030. ${ }^{17}$ Second, all household incomes are adjusted proportionally so that the percentage change in weighted average aggregate of household incomes in the GIDD is consistent with the CGE model's estimate of the percentage change in real income.

The first step in the microsimulation exercise is to implement a set of changes in the household surveys' demographic structure, as explained in Section 3.5. The second step is to adjust factor returns by skill and sector in accordance with the results of the CGE model. The GIDD imposes a new vector of earnings on each worker, conditional on that worker being in sector $s$ and having educational attainment $e$. In the third step, we proportionally adjust the per capita income of each household to guarantee that the weighted average of household incomes changes exactly in line with the CGE results. Lastly, GIDD constructs a householdspecific deflator to adjust for changes in relative prices. We construct the price using initial and final prices indices of food versus non-food from the CGE model and household-specific budget consumption shares for food and non-food observed in microdata.

\section{Key Data: Estimates of the AVEs of Trade Costs, Population Projections and FDI Shares}

The core dataset for the CGE analysis is the set of input-output tables from version 8.1 of GTAP. ${ }^{18}$ We use the International Income Distribution Dataset (I2D2) for the household datasets of our microsimulation model. The I2D2 is a global harmonised household survey database of 120 countries that are comparable across countries and time. It contains data on household income and consumption and individual data on education, demographics and labour force participation (see Montenegro and Hirn (2009) for documentation).

Given the primary importance of the AVEs of the barriers against foreign suppliers of services, the time in trade costs and the non-tariff barriers, we discuss those estimates here. Since it involves a new dataset, we also discuss the estimates of the shares of domestic services markets captured by foreign direct investors. Full documentation of the dataset is available in Balistreri et al. (2016). Finally, given their importance for our 2030 CGE model and the microsimulation work, we also discuss the population and skill mix projections.

\subsection{AVEs of the barriers against foreign suppliers of business services}

Our estimates build on the World Bank database of discriminatory regulatory barriers in 11 services sectors in 103 countries described in Borchert et al. (2014). ${ }^{19}$ The work of Borchert et al. (2014) produced Services Trade Restrictiveness Indices (STRIs), but not

17 The aggregate returns to capital and labour in the CGE model, however, are not aligned with the household data. See Rutherford and Tarr (2008) for a discussion of the impact of reconciliation of the factor returns in the household data with the input-output table.

18 See https://www.gtap.agecon.purdue.edu/. Accessed August 17, 2017.

19 In the cases of Kenya and Tanzania, we commissioned new surveys by local law firms of the regulatory regimes in services as a basis of estimating both the non-discriminatory barriers that impact 
AVEs. Jafari and Tarr (2015) transformed the data on the discriminatory regulatory barriers against foreign services providers in these sectors and countries into AVEs. In this article, we employ the estimates of Jafari and Tarr (2015).

Compiling a comprehensive and detailed database on discriminatory regulatory barriers in services is both time and resource intensive. As a result, authors, including Francois et al. (2007), Kimura and Lee (2004) and Fontagné et al. (2016), have attempted to estimate barriers against services providers based on a gravity model. An important limitation of this approach is that the estimates are based on cross-border trade in services only; ${ }^{20}$ so estimates from this approach are not available for barriers against foreign direct investment. But in services, the data show that sales through foreign direct investment are more important. Moreover, as Francois and Hoekman (2010) noted, a well-known limitation of the gravity approach is that the AVE is not related to any specific regulatory barrier. Our experience has shown that in-country officials are often deeply skeptical or unconvinced of such estimates unless the researcher can point to specific regulatory barriers in particular sectors; but when specific barriers can be referenced, the story typically becomes convincing. Further, without tying the AVEs and the costs of the barriers to specific regulatory barriers, the analyst is not able to recommend potential policy reforms. Consequently, we prefer to use estimates that are based on the Borchert et al. database on services regulatory barriers.

\subsection{Estimates of the AVEs of the costs of time in exporting and importing}

To estimate the impact of improved trade facilitation, in this article we apply a new dataset based on the path-breaking work of David Hummels and his co-authors (Hummels et al., 2007; Hummels and Schaur, 2013). These authors estimate the time cost of trade by product and country in two steps: (1) they first estimate the cost of one-day delay by product; and (2) they combine their estimates of the per day cost of trade by product with the World Bank's Doing Business database on the number of days to export or import by country. This yields the costs by product and country. Since the product mix with a sector in a CGE model will vary on a bilateral basis, Minor (2013) used the estimates of Hummels et al. (2007) and provided estimates for the regions and products in the GTAP database on a bilateral basis. We use estimates from Peter Minor, which we aggregate to the sectors and regions of our model, yielding the cost of trade by product and country on a bilateral trade basis. Detailed documentation of the steps we have taken, a brief explanation of the methodology and a detailed explanation of our aggregation methodology are available in Balistreri et al. (2014, 2015b).

\subsection{Estimates of the AVEs for non-tariff measures}

Our estimates of the AVEs of non-tariff measure (NTMs) are based on the estimates of Kee et al. (2009). The measure we use from Kee et al. is the uniform tariff equivalent that generates the same level of import value for the country in a given year, based on applied tariffs, which takes into account bilateral trade preferences. To avoid wide margins of error at the sector level, we have chosen to use the aggregated estimates of Kee et al., i.e., for each country, we have two AVEs: one AVE of the NTMs in manufacturing and one AVE of the

both domestic and foreign suppliers of services as well as the discriminatory regulatory barriers against foreign suppliers of services.

20 Francois et al. (2007) incorporate some data on FDI. 
NTMs in agriculture. ${ }^{21}$ In Table 2, we display all the distortions in the model for Tanzania. Tanzania has the highest AVEs for manufactured goods at $47.4 \%$ and, at $22.2 \%$ for agriculture, is among the highest. ${ }^{22}$ We then further aggregate these values for 93 countries to the regions of our model. Details are available in Appendix B of Balistreri et al. (2014). Where the NTM has a legitimate regulatory function, we assume that the estimate of Kee et al. is the discriminatory component of the regulation.

The report of the East African Community (2012) shows that non-tariff barriers remain a very significant problem. Consequently, we assume the AVEs of the non-tariff barriers apply to all countries.

\subsection{Share of market captured by foreign direct investors in services and by cross-border sales of services}

For cross-border sales of services, we use the trade data from the GTAP 8.1 dataset. Our primary data source for foreign affiliate sales is the database developed by Fukui and Lakatos (2012). Fukui and Lakatos combine Eurostat data for 41 countries with an econometric model to estimate the missing values and thus produce estimates for all regions and sectors in the GTAP dataset. For the share of sales in the sector by the host country, we use the GTAP dataset for total sales in the sector and subtract the total of foreign affiliate sales from total sales to obtain the host country share of sales. In the insurance, banking, telecommunications and professional services sectors for our African regions, we used supplementary sources discussed in Appendices D and E of Balistreri et al. (2014).

\subsection{Population and skill mix of the labour force}

Starting with our household survey, the country specific demographic profiles are constructed by partitioning each country's total population into: (1) 16 age-groups (0-4, 5-9, $10-14, \ldots, 65-69,70-74,75$ and above); (2) two gender groups; and (3) three distinct levels of educational attainment: (i) no-education or primary only; (ii) secondary education; and (iii) tertiary education. For 2030, our age and gender projections are taken from the medium variant population projections of United Nations Department of Economic and Social Affairs (2015). In terms of education, we assume that as the population ages, the average educational attainment in a country increases through a pure pipeline effect, as younger and more educated cohorts replace older cohorts. For example, if at time $t$ half of

21 Whether to aggregate elasticities or not is a complex question that depends on the sector focus of the research and the confidence in the reliability of sector estimates. In addition to the estimates of Kee et al. (2009) that differ by sector, there are other estimates of NTMs that differ by sector, such as in Cadot and Gourdon (2014) and de Melo and Vijil (2016). The problem is, as expressed by Costinot and Rodriguez-Clare (2014) 'as the number of elasticities [and AVEs] that needs to be estimated increases, the precision with which each of these elasticities is estimated tends to decrease. Accordingly, results become much more sensitive to the presence of outliers'. They note that estimates by Caliendo and Parro at the sector level would imply infinite gains from trade in autos. In an earlier application of our CGE model (BTY 2015b), we found that results were also driven by outliers when we employed sector estimates of AVEs. Since we did not find evidence to support the wide variation in sector AVE estimates, we reverted to the more aggregate approach.

22 The AVEs for the other African regions are (manufacturing goods first, then agricultural goods): Kenya: 0.3 and 14.6\%; Uganda: 0.0, 3.9\%; Rwanda: 4.8\%, 0.0; COMESA: 20.1, 27.5\%; SADC: $0.4,4.5 \%$. 
Table 2: Benchmark Distortions in Tanzania; Ad valorem values in percentage

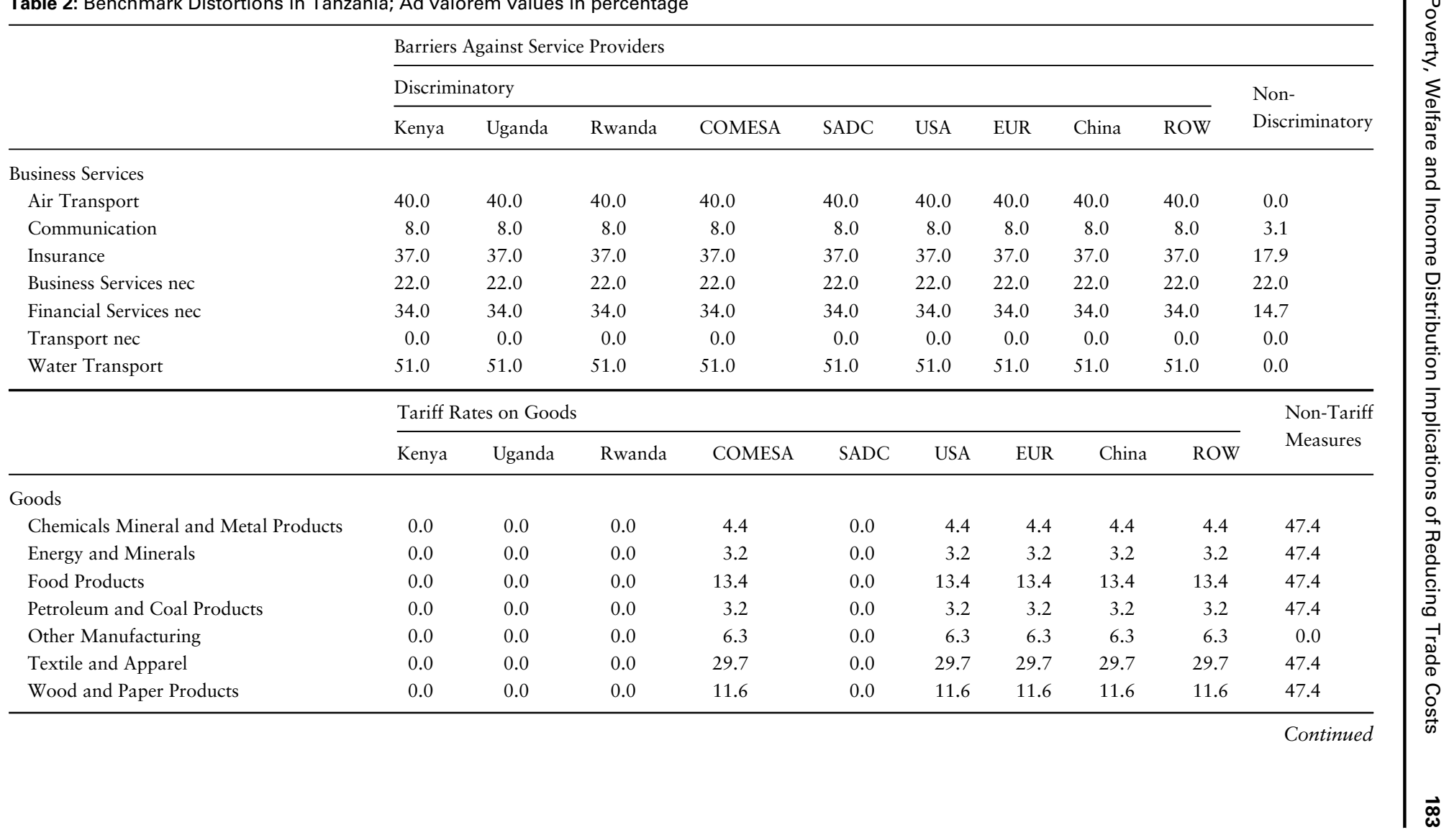


Table 2: Continued

\begin{tabular}{|c|c|c|c|c|c|c|c|c|c|c|}
\hline & \multicolumn{9}{|c|}{ Tariff Rates on Goods } & \multirow{2}{*}{$\begin{array}{l}\text { Non-Tariff } \\
\text { Measures }\end{array}$} \\
\hline & Kenya & Uganda & Rwanda & COMESA & SADC & USA & EUR & China & ROW & \\
\hline \multirow[t]{2}{*}{ Agriculture and Forestry } & 0.0 & 0.0 & 0.0 & 11.9 & 0.0 & 11.9 & 11.9 & 11.9 & 11.9 & 47.4 \\
\hline & \multicolumn{9}{|c|}{ Barriers to Efficient Trade Facilitation on Exports } & \\
\hline Chemicals Mineral and Metal Products & 16.2 & 16.1 & 14.2 & 14.0 & 16.1 & 12.9 & 13.7 & 15.9 & 16.2 & \\
\hline Energy and Minerals & 9.0 & 7.6 & 9.0 & 9.0 & 5.4 & 5.4 & 8.6 & 9.0 & 8.4 & \\
\hline Food Products & 12.6 & 15.3 & 16.4 & 12.1 & 13.8 & 7.6 & 14.7 & 9.8 & 13.9 & \\
\hline Petroleum and Coal Products & 19.9 & 19.9 & 19.9 & 19.9 & 19.9 & 19.9 & 19.9 & 19.9 & 19.9 & \\
\hline Other Manufacturing & 7.8 & 6.4 & 13.1 & 10.2 & 10.2 & 9.4 & 9.3 & 9.8 & 9.6 & \\
\hline Textile and Apparel & 5.9 & 5.7 & 5.8 & 5.6 & 6.3 & 6.8 & 7.2 & 6.6 & 7.5 & \\
\hline Wood and Paper Products & 8.3 & 15.1 & 11.2 & 10.8 & 9.5 & 5.8 & 6.3 & 4.3 & 15.2 & \\
\hline \multirow[t]{2}{*}{ Agriculture and Forestry } & 14.3 & 18.2 & 28.7 & 12.5 & 17.6 & 17.9 & 15.2 & 13.1 & 18.0 & \\
\hline & \multicolumn{9}{|c|}{ Barriers to Efficient Trade Facilitation on Imports } & \\
\hline Chemicals Mineral and Metal Products & 19.9 & 38.6 & 58.8 & 9.2 & 29.3 & 4.8 & 5.9 & 14.8 & 13.5 & \\
\hline Energy and Minerals & 11.7 & 18.9 & 19.8 & 4.5 & 17.3 & 2.6 & 3.9 & 8.2 & 9.2 & \\
\hline Food Products & 20.7 & 30.7 & 27.9 & 41.9 & 19.7 & 4.8 & 4.8 & 11.3 & 10.8 & \\
\hline Petroleum and Coal Products & 25.9 & 41.9 & 43.9 & 38.1 & 36.0 & 6.0 & 14.1 & 18.0 & 17.8 & \\
\hline Other Manufacturing & 15.1 & 26.9 & 42.6 & 3.4 & 16.3 & 2.0 & 4.1 & 8.6 & 8.2 & \\
\hline Textile and Apparel & 6.5 & 12.8 & 13.8 & 5.3 & 15.0 & 2.1 & 3.9 & 5.9 & 7.2 & \\
\hline Wood and Paper Products & 14.7 & 17.6 & 49.9 & 10.8 & 33.9 & 2.6 & 7.9 & 9.6 & 9.7 & \\
\hline Agriculture and Forestry & 19.8 & 34.7 & 54.2 & 20.4 & 30.3 & 8.7 & 9.0 & 17.9 & 15.6 & \\
\hline
\end{tabular}


the population in the cohort formed by individuals between 25 and 30 years of age have post-secondary education, then after 10 years (at $t+10)$, half of the population between 35 and 40 will have post-secondary education. Furthermore, for younger cohorts we imposed the assumption that there is no improvement in enrolment and graduation rates from those observed at time $t$. In other words, the average educational attainment of these young cohorts in the future is equal to the average educational levels of the 20-24 cohort of time $t$. This is a conservative assumption given that the 20-24 cohorts observed at time $t$ may not have the maximum educational level attainable. ${ }^{23}$

\section{CGE Results: Deep Integration in Eastern and Southern Africa}

To assess the importance of wider integration, we evaluate the impacts of deep integration to reduce trade costs at three levels of integration: (1) deep integration within the EACU alone; (2) unilateral liberalisation of the same policies by the EACU countries toward the entire world; and (3) deep integration within the Tripartite FTA. We also decompose each of the three broad deep integration policies into their three components: trade facilitation; reduction of non-tariff barriers; and services liberalisation. The decomposition allows us to infer the relative importance of the various reforms to the different countries within each broad policy scenario. In all scenarios, we assume that the barriers impose real resource costs, so liberalisation generates both 'rectangles' of gains from additional capital and labour that are available, as well as 'Harberger triangles' of efficiency gains. ${ }^{24}$ In Balistreri et al. (2015a), we conduct sensitivity analysis on this assumption. We note that all prices are relative in this model and trade costs are included in the price of the product; so, when we change the trade costs of a product in a country, we change its price relative to all prices, domestic and foreign, inclusive of their trade costs. Thus, our model, and most multicountry CGE models, employ and approach analogous to the suggestion of Yotov (2012) to the resolution of the distance puzzle in gravity models. ${ }^{25}$

23 The microsimulation model recalibrates each household sample weight to match the age, gender, and education projected totals such that the new sets of age, gender and education deviate as little as possible from the initial distributions. See Wittenberg (2010) for a technical description and implementation of this method.

24 For the intuition regarding rectangles and triangles, consider the example of trucks queuing at customs posts or ships queuing in a harbour. Capital and labour is being used in the delay. If trade facilitation is improved, reducing delay time, then the cost of delivering the product will fall on the entire quantity of initial shipments. The initial quantity times the cost saving is a 'rectangle'. In addition, the lower costs of transport services will induce additional shipments. The additional gains, in partial equilibrium, are triangles equal to one half the change in quantity times the change in costs.

25 For background, the 'distance puzzle' emerged because, despite the increase in global trade and greater integration, gravity models that only consider international distance-related costs failed to show a decline in the importance of distance over time. In the context of solving the 'distance puzzle', Yotov (2012) emphasised the importance of changing trade costs relative to all other costs (domestic and international). Yotov finds that international distance-related costs do, in fact, decline over time (as expected), once we consider that these must be interpreted relative to domestic costs. In the context of our analysis, our treatment is consistent with theory in that our price normalisation is explicit, and any change in trade costs is done relative to all other (domestic and international) trade costs. 


\subsection{Scenario definition and rationale}

Table 3 presents the results from our 12 scenarios for the variables important in the microsimulation analysis; it also contains a chart that defines the components of the scenario. We label the results of our 12 scenarios as S.1-S.12 in Table 3. These scenarios and their rationale are defined as follows.

Scenario 1 (S.1). Business as Usual. Exogenous increase in the labour force and endogenous increase in the capital stock, with investment adjustment.

To isolate the impacts of the trade policies, we create a 'Business as Usual' (BAU) scenario for 2030. The BAU scenario includes an exogenous increase in the labour force categories and an endogenous determination of the capital stock, as discussed in Section 2.2. BAU excludes trade policy changes. The scenarios for trade policy impacts for 2030 are presented as differences from the BAU scenario, and thereby are the trade policy impacts alone, excluding the impact of the labour market expansion and the endogenous change in the capital stock due to the labour force expansion. There is an endogenous capital stock change in the trade policy scenarios for 2030, but it is attributable to the impact on the real return to capital from the trade policy change alone, not the increase in the labour force. ${ }^{26}$

Scenario 2 (S.2). EACU Central. This constitutes:

(i) Trade Facilitation, 20\% cut in AVE of the time in trade costs within the EACU and a $5 \%$ cut in these costs for trade with countries outside the EACU.

(ii) Services liberalisation, 50\% cut in the AVEs of services barriers within the EACU.

(iii) Non-tariff barriers reduction, $20 \%$ cut in the AVEs of the NTBs within the EACU, with zero cut for countries outside the EACU.

As members of a customs union, we assume that the EACU members act collectively on all actions in our scenarios. We assume that tariff free trade prevails within each of the three regional groups of the Tripartite FTA, but the barriers that lead to high trade costs apply to all countries and regions. In Table 2, we show the benchmark ad valorem rates of distortion for all barriers we apply for Tanzania. See Balistreri et al. (2016) for the comparable tables for all six African regions of our model.

Regarding trade facilitation, we take modest cuts for multiple reasons. One is that the most efficient countries in the world have positive time costs of trade. Second, part of the costs is due to infrastructure deficiencies that cannot be addressed through policy alone. There are, however, some collaborative projects and plans among members of the EACU (East African Community Secretariat, 2011), such as common customs posts, designed to cut the time costs of trade. Since there is likely a spillover benefit of these measures within the EACU that will cut the time costs of trade outside of the EACU, we assume cuts in external trade costs as well.

26 We obtain the values for the trade policy changes in Table 3 as follows. For each trade policy scenario, we exogenously impose the 2030 labour force and the trade policy changes and then execute a simulation in our comparative steady-state model. From the estimates of these simulations, we subtract the estimated change of the BAU scenario to obtain the values in Table 3 . This isolates the trade policy impacts since the BAU scenario contains the same exogenous labour force expansion. 
Table 3: Deep Integration within the Tripartite FTA and the East Africa Customs Union (EAC) and Unilateral Reforms by the EACU Results for 2030-(Trade Policy Results are Percentage Change From BAU for 2030)

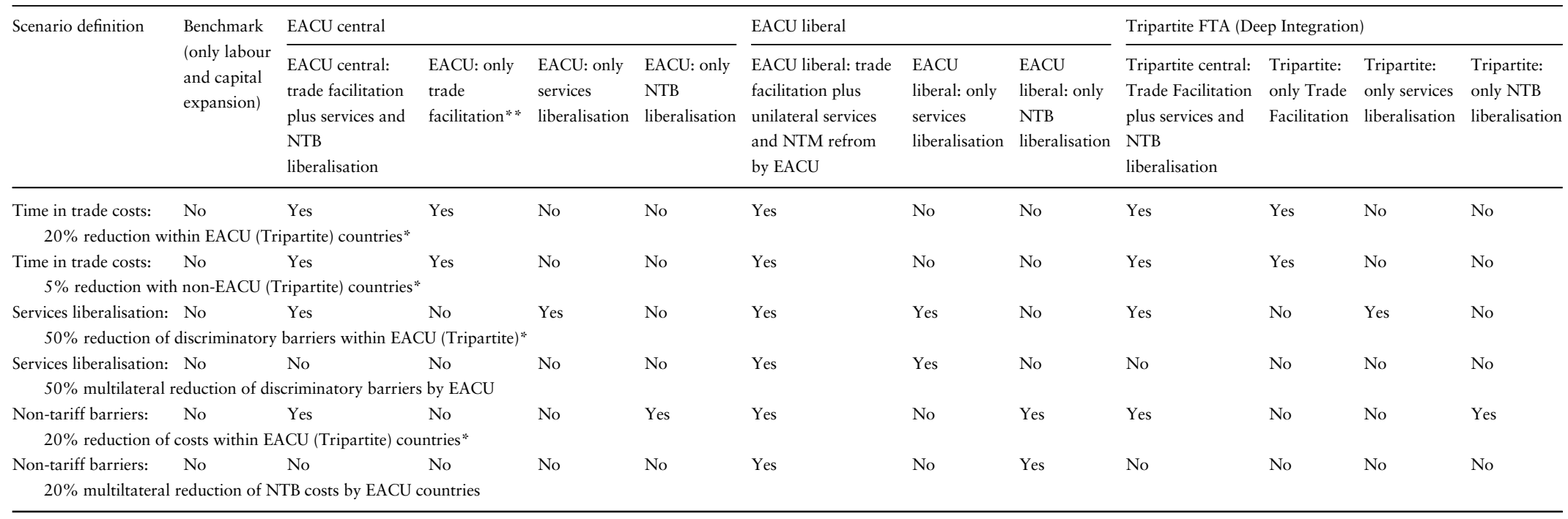


Table 3: Continued

\begin{tabular}{|c|c|c|c|c|c|c|c|c|c|c|c|c|}
\hline \multirow[t]{2}{*}{ Scenario definition } & \multirow{2}{*}{$\begin{array}{l}\text { Benchmark } \\
\text { (only labour } \\
\text { and capital } \\
\text { expansion) }\end{array}$} & \multicolumn{4}{|l|}{ EACU central } & \multicolumn{3}{|l|}{ EACU liberal } & \multicolumn{4}{|c|}{ Tripartite FTA (Deep Integration) } \\
\hline & & $\begin{array}{l}\text { EACU central: } \\
\text { trade facilitation } \\
\text { plus services and } \\
\text { NTB } \\
\text { liberalisation }\end{array}$ & $\begin{array}{l}\text { EACU: only } \\
\text { trade } \\
\text { facilitation* * }\end{array}$ & $\begin{array}{l}\text { EACU: only } \\
\text { services } \\
\text { liberalisation }\end{array}$ & $\begin{array}{l}\text { EACU: only } \\
\text { NTB } \\
\text { liberalisation }\end{array}$ & $\begin{array}{l}\text { EACU liberal: trade } \\
\text { facilitation plus } \\
\text { unilateral services } \\
\text { and NTM refrom } \\
\text { by EACU }\end{array}$ & $\begin{array}{l}\text { EACU } \\
\text { liberal: only } \\
\text { services } \\
\text { liberalisation }\end{array}$ & $\begin{array}{l}\text { EACU } \\
\text { liberal: only } \\
\text { NTB } \\
\text { liberalisation }\end{array}$ & $\begin{array}{l}\text { Tripartite central: } \\
\text { Trade Facilitation } \\
\text { plus services and } \\
\text { NTB } \\
\text { liberalisation }\end{array}$ & $\begin{array}{l}\text { Tripartite: } \\
\text { only Trade } \\
\text { Facilitation }\end{array}$ & $\begin{array}{l}\text { Tripartite: } \\
\text { only services } \\
\text { liberalisation }\end{array}$ & $\begin{array}{l}\text { Tripartite: } \\
\text { only NTB } \\
\text { liberalisation }\end{array}$ \\
\hline Scenario number & S.1 & S.2 & S.3 & S.4 & S.5 & S.6 & S.7 & S.8 & S.9 & S.10 & S.11 & S.12 \\
\hline \multicolumn{13}{|c|}{ Hicksian equivalent variation divided by population increase and initial consumption } \\
\hline Kenya & 45.4 & 3.78 & 2.23 & 0.23 & 0.90 & 8.30 & 5.38 & 0.47 & 7.46 & 3.72 & 2.31 & 1.02 \\
\hline Tanzania & 20.7 & 1.76 & 1.08 & 0.03 & 0.37 & 9.68 & 2.35 & 5.69 & 4.47 & 2.33 & 0.30 & 0.99 \\
\hline Uganda & 37.1 & 1.01 & 0.85 & 0.16 & 0.05 & 6.46 & 5.39 & 0.13 & 3.80 & 3.22 & 0.39 & 0.11 \\
\hline Rwanda & 17.4 & 2.15 & 1.62 & 0.32 & 0.07 & 11.11 & 8.40 & 0.22 & 3.37 & 2.28 & 0.48 & 0.17 \\
\hline COMESA & 20.9 & 0.00 & 0.00 & 0.00 & 0.00 & 0.00 & 0.00 & 0.00 & 2.39 & 0.32 & 1.90 & 0.04 \\
\hline SADC & 45.4 & 0.00 & 0.01 & 0.00 & 0.00 & 0.04 & 0.01 & 0.02 & 1.55 & 1.01 & 0.52 & 0.08 \\
\hline \multicolumn{13}{|l|}{ Unskilled wage } \\
\hline Kenya & 32.11 & 3.81 & 2.36 & 0.21 & 0.89 & 8.25 & 5.33 & 0.34 & 7.04 & 3.86 & 1.56 & 1.34 \\
\hline Tanzania & 9.86 & 2.37 & 1.35 & 0.02 & 0.72 & 8.17 & 1.72 & 4.65 & 5.05 & 2.51 & 0.21 & 1.46 \\
\hline Uganda & 16.39 & 5.44 & 4.64 & 0.10 & 0.31 & 8.61 & 3.64 & 0.10 & 8.38 & 6.47 & 0.29 & 0.78 \\
\hline Rwanda & 9.78 & 3.11 & 2.38 & 0.24 & 0.11 & 8.91 & 6.46 & 0.16 & 11.34 & 7.97 & 0.35 & 0.33 \\
\hline COMESA & 16.96 & 0.00 & 0.00 & 0.00 & 0.00 & 0.01 & 0.00 & 0.00 & 2.29 & 0.36 & 1.86 & 0.02 \\
\hline SADC & 25.78 & 0.00 & 0.01 & 0.00 & 0.00 & 0.04 & 0.01 & 0.02 & 2.14 & 1.06 & 0.38 & 0.12 \\
\hline \multicolumn{13}{|l|}{ Non-agriculture } \\
\hline Kenya & 35.07 & 4.16 & 2.51 & 0.22 & 1.02 & 8.71 & 5.52 & 0.42 & 6.90 & 3.80 & 1.50 & 1.25 \\
\hline Tanzania & 10.00 & 1.92 & 1.08 & 0.02 & 0.52 & 8.09 & 1.96 & 4.57 & 4.61 & 2.32 & 0.26 & 1.18 \\
\hline Uganda & 18.30 & 3.41 & 2.87 & 0.11 & 0.21 & 6.95 & 3.79 & 0.12 & 6.01 & 4.70 & 0.31 & 0.51 \\
\hline Rwanda & 9.86 & 2.40 & 1.83 & 0.27 & 0.08 & 9.37 & 6.94 & 0.13 & 5.75 & 4.05 & 0.39 & 0.22 \\
\hline COMESA & 18.11 & 0.00 & 0.00 & 0.00 & 0.00 & 0.01 & 0.00 & 0.00 & 2.33 & 0.25 & 1.94 & 0.02 \\
\hline SADC & 25.59 & 0.00 & 0.01 & 0.00 & 0.00 & 0.03 & 0.00 & 0.01 & 1.17 & 0.72 & 0.38 & 0.08 \\
\hline
\end{tabular}

"Reductions apply to the EACU or the Tripartite countries depending on the scenario.

** Trade facilitation within the 'EACU Liberal' scenario is the same as Scenario 3, Trade Facilitation within the EACU.

Source: Authors' estimates. 
With respect to non-tariff barriers, under the auspices of the East African Community, the member countries are undertaking collaborative efforts to reduce non-tariff barriers (East African Community, 2012). NTM, however, have become much more subtle in the post-Uruguay Round world. Most measures have a legitimate regulatory function and distinguishing the legitimate regulations from protective or inefficient regulations is complicated. Consequently, we take a more modest $20 \%$ reduction in the AVE of these barriers, with no spillover to countries excluded from the agreement.

For barriers on foreign providers of services, on 1 July 2010, the East African Community adopted a Common Market protocol that called for the free movement of services within the five-member states, along with the free movement of goods, capital and labour. $^{27}$

Scenarios 3, 4 and 5 (S.3, S.4 and S.5). The components of EACU Central, Scenario 2. Only Trade Facilitation, Only Services Liberalisation and only reduction of Non-Tariff Barriers, respectively.

Scenario 6 (S.6). EACU Liberal. This constitutes unilateral liberalisation by the EACU countries as follows:

(i) Trade facilitation, 20\% cut in AVE of the time in trade costs within the EACU and a $5 \%$ cut in these costs for trade with countries outside the EACU.

(ii) Services liberalisation, $50 \%$ cut in the AVEs of services barriers for all countries.

(iii) Non-tariff barriers reduction, $20 \%$ cut in the AVEs of the NTBs for all countries.

With a combined nominal GDP in 2013 of only about US\$121 billion (or US\$297 billion on a purchasing power parity basis), ${ }^{28}$ the EACU is not a large market, and economic theory indicates that there should be substantially greater gains from integrating into the world trading environment. In 'EACU Liberal,' we assess how much more could be gained extending the liberalisations of non-tariff barrier and services barriers implemented in 'EACU Central' to all trading partners in the world. In the case of the time in trade costs, however, we do not extend these outside of the EACU since the improvements are primarily regional and reciprocal and we already convey a $5 \%$ cut in these barriers for countries outside of the EACU.

Scenarios 7 and 8 (S.7, S.8). EACU countries implement only services liberalisation or only reduction of non-tariff barriers, respectively, for all countries.

Scenario 9. Tripartite Central. This constitutes:

(i) Trade facilitation, $20 \%$ cut in AVE of the time in trade costs within the Tripartite FTA and a $5 \%$ cut in these costs for trade with countries outside the Tripartite FTA.

27 For a summary of the components of the East African Common Market see: http://eac.int/ integration-pillars/common-market (last accessed August 17, 2017). In this model, we do not incorporate reforms that would impact the free movement of capital and only partially capture the free movement of labour through the reduction of barriers to foreign suppliers of services.

28 In 2013, the International Monetary Fund estimated the nominal GDP of the EACU members as follows (in billions of US dollars): Kenya, 55; Tanzania, 33.3; Uganda, 22.9; Rwanda, 7.4; and Burundi, 2.7. The purchasing power parity GDP, however, was estimated by the IMF at: Kenya, 125.8; Tanzania, 84.9; Uganda, 61.9; Rwanda, 17.4; and Burundi, 7.9. 
(ii) Services liberalisation, $50 \%$ cut in the AVEs of services barriers within the Tripartite FTA.

(iii) Non-tariff barriers reduction, 20\% cut in the AVEs of the NTBs within the Tripartite FTA, with zero cut for countries outside the region.

The Second Tripartite Summit in June 2011 envisioned liberalisation of trade in goods and movement of business persons in Phase I and, in Phase II, liberalisation of trade in services and related trade areas. Programmes of trade and transport facilitation and NTB removal have been launched. ${ }^{29}$ In our Tripartite Central scenario, we assume all six of our Tripartite-African regions (Kenya, Tanzania, Rwanda, Uganda, COMESA and SADC) execute identical preferential liberalisation of the time costs of trade, non-tariff barriers and services liberalisation as we implemented in the EACU Central scenario, except that the preferences apply throughout the Tripartite FTA.

Scenarios 10, 11 and 12 (S.10, S.11 and S.12). The three components of Scenario 9, respectively, each in isolation.

\subsection{Aggregate welfare effects}

Real income gains in the BAU scenario are substantial, ranging from $17 \%$ for Rwanda to $45 \%$ for Kenya and SADC. The large gains are due to two factors: the labour force is projected to grow faster than the population and the capital stock increases.

Comparing welfare results in Scenarios 2, 6 and 9, we see that, for Tanzania, Uganda and Rwanda, we have the expected result that the wider the integration, the greater the gains. Integrating with the larger Tripartite FTA yields larger gains than limiting deep integration to within the EACU only, and unilateral liberalisation dominates Tripartite liberalisation. In the case of Kenya, the gains from deep integration in the Tripartite FTA are $90 \%$ of the gains from wider liberalisation with the entire world; in the comparative static model of BTY (2015b), however, the gains to Kenya are larger in the Tripartite scenario (S.9) compared with EACU liberal (S.6). Our decomposition analysis provides intuition into the reasons for these results.

\subsection{Reduction of time in trade costs (trade facilitation)}

\subsubsection{Relative importance of trade facilitation}

Trade facilitation is the largest component of the gains in both the EACU Central and the Tripartite scenarios for all countries except for COMESA in the Tripartite scenario. For equivalent AVEs, trade facilitation is more important than non-tariff barriers to the welfare results since it reduces the time costs of trade on both imports and exports, whereas the reduction on non-tariff barriers only reduces costs of imports. Services liberalisation is less important in our dataset since, with limited exceptions discussed below, the six regions have limited penetration into the services markets of each other.

For the COMESA and SADC regions, the gains from the reduction in the time costs of trade are considerably less than for the four EACU countries. The reason is that the COMESA and SADC regions trade much more intensively with countries outside of the Tripartite FTA, where we assume there are fewer opportunities for reductions in time in trade costs. The trade-weighted import intensities of goods trade with regions outside of

29 See Pearson (2012) and Willenbockel (2013) for details. 
the Tripartite FTA are as follows: Kenya, 86.7\%; Tanzania, $84.7 \%$; Uganda, $70.7 \%$; Rwanda, 63.1\%; COMESA, 97.6\%; and SADC, $99.3 \%$.

Second, despite wider liberalisation in the EACU Liberal scenario, the trade facilitation gains for the EACU countries are larger in the Tripartite scenario than they are in the EACU Liberal scenario. This is because of our assumption that the trade facilitation reforms, such as road and border crossing improvements, disproportionately reduce the costs of the local countries implementing the reforms. Our Tripartite scenario widens the regions to which the larger $20 \%$ cuts apply, but the EACU Liberal scenario applies a $5 \%$ cut in these costs on trade outside of the EACU.

\subsubsection{Larger gains for agricultural exporters}

Previous efforts at simulating sector output and export changes from trade facilitation used uniform AVEs across sectors, which tended to result in more uniform impacts across sectors. Our dataset has the time costs of trade varying by both product and by country of origin and destination. ${ }^{30}$ Since the time costs of trade tend to be highest in agricultural products, trade facilitation tends to favour agriculture and to favour disproportionately countries that intensively export agricultural products. This is especially important in explaining results for Uganda (and to a lesser extent for Rwanda). Agriculture is a Ugandan sector with one of our highest estimated AVE of the time costs of exporting (importing); the Ugandan AVE in agriculture is about 40 (30) percent, depending on the destination (origin) country. ${ }^{31}$ Consequently, from trade facilitation, we estimate an expansion of agricultural output and exports in Uganda relative to other sectors; and $85 \%$ of Ugandan gains from the Tripartite FTA are due to trade facilitation gains.

\subsection{Reduction of non-tariff barriers}

The results are very striking for both Tanzania and Kenya. We estimate a big increase in welfare for Tanzania from the reduction of non-tariff barriers toward the entire world in the EACU Liberal scenario (S.8). The wider liberalisation of non-tariff barriers results in a welfare gain of more than $5.7 \%$ of consumption, whereas the welfare gains are only $0.99 \%$ of consumption in the Tripartite scenario (S.12). This large gain in EACU Liberal for Tanzania is explained by two factors: (1) the AVEs of the non-tariff barriers in Tanzania are $47.4 \%$ in manufacturing and $22.2 \%$ in agriculture. The manufacturing AVEs are substantially higher than the estimates for the other African countries or regions in our model and the agricultural AVEs are second only to COMESA (see footnote 22); and (2) on a trade-weighted basis, $84.7 \%$ of Tanzania's trade is with countries outside of the Tripartite FTA. Thus, the reduction of NTB barriers impacts a much larger share of trade, generating more recaptured rents and greater efficiency gains.

For Kenya, perhaps surprisingly, Kenya gains more from preferential NTB liberalisation in the Tripartite FTA (S.12) than from equivalent unilateral liberalisation of EACU Liberal scenario (S.8). This is due to preferential market access in goods. The theory paper of Wonnacott and Wonnacott (1981) emphasised that improved market access in export markets of goods could lead to preferential trade agreements dominating unilateral trade

30 The AVEs differ across countries, due to the product mix differences across countries of the aggregated sectors of our model.

31 The partner country AVE is also relevant in assessing impacts. 
liberalisation; and an example of this with real data was first shown by Harrison et al. (2002). Our result for Kenya provides another example in which preferential agreements can yield larger gains than unilateral liberalisation due to market access gains.

For COMESA and SADC, the gains are negligible from a cut in the AVEs of the NTBs in the Tripartite FTA. This is because the share of their trade within the Tripartite region is so small: only $2.4 \%$ for COMESA and $0.7 \%$ for SADC.

\subsection{Reduction of barriers against foreign service providers}

Uganda, Kenya and especially Rwanda reap very large gains from reducing barriers against all suppliers of services in the world (S.7). For Rwanda, the AVEs of barriers against foreign providers of services are substantial, with four sectors in Rwanda having AVEs of between 25 and $62 \%$. Further, except for Kenyan insurance firms, the market share of EACU firms in Rwanda is very small in services. But the main foreign service suppliers in Rwanda (see Table 6d of Balistreri et al., 2014) are European Union suppliers followed by the United States and the Rest of the World. COMESA's share in Rwanda's service markets is zero and SADC is represented in Rwanda only in telecommunications $(36 \%)$ and insurance $(4 \%)$. Therefore, compared with multilateral liberalisation, Rwanda's gains much less from liberalisation of services markets in the Tripartite FTA since the Tripartite FTA yields additional services suppliers only from SADC and only in telecommunications and insurance.

Two regions gain substantially from services liberalisation within the Tripartite FTA. One is Kenya, which, gains $2.31 \%$ of consumption in the Tripartite 'only services liberalisation' scenario. The reason is that Kenya has a significant share of the insurance markets in COMESA, where we estimate a very high AVE of the barriers to services providers. The improved market access for Kenyan insurance suppliers under the protected umbrella of very high barriers creates substantial gains for insurance services suppliers from Kenya in COMESA markets. We verified this explanation by executing a scenario in which we preferentially liberalise services barriers within the Tripartite area, but exclude preferential reduction in insurance services barriers. In this scenario, the estimated gains to Kenya from 'only services liberalisation' within Tripartite fall dramatically from 2.31 to $0.7 \%$ of consumption.

The other region that reaps substantial gains from services reform in the Tripartite area is COMESA. This is explained by the high services barriers in COMESA, especially in insurance where Kenya has a presence in the markets of COMESA. Reduction of services barriers in COMESA generates gains in part since it frees up capital and labour required to comply with the protective or inefficient regulation as well as efficiency gains from better access to relatively efficient services suppliers.

We note that the gravity approach to an assessment of the gains from reducing trade costs, such as in the Caliendo and Parro (2015) and Caliendo et al. (2015) papers, does not take foreign direct investment into account. In the case of EACU Liberal, the gains from the liberalisation of barriers against foreign direct investment as a percentage of the total gains (ratio of column S.7 divided by column S.6) are Kenya, 65\%; Tanzania, 24\%; Uganda, $83 \%$; and Rwanda, $76 \%$. Thus, any approach, including the gravity approach that ignores barriers against foreign service providers, notably foreign direct investment, will miss most of the impacts in some cases. 


\section{Poverty and Income Distribution Results of Deep Integration in East and Southern Africa}

\subsection{Poverty headcount and percentage of the population living in poverty}

Results for the percentage of the population below the poverty line and the poverty headcount are in the top two sections of Table 4 . We define the poverty line as $\$ 1.25$ per day on a purchasing power parity (PPP) basis. In the Tripartite scenario, the results indicate a net reduction in the poverty headcount for all six of our African regions, varying between 0.48 million people in Rwanda to 1.63 million in SADC, with a reduction in the poverty headcount in the EACU of 4.19 million. We estimate that the largest percentage point reduction of poverty is in Rwanda (2.70), but the largest reduction in the percentage of people living in poverty is in Uganda (14\%). Unilateral liberalisation by the EACU members would lift even more out of poverty-an estimated 5.14 million people in the EACU region would be lifted out of poverty.

\subsection{Income distribution results}

\subsubsection{Impact on the incomes of the poorest $40 \%$}

Both deep integration in the Tripartite FTA and unilateral liberalisation would significantly increase the incomes of the poorest $40 \%$ of the population. We estimate that as a result reduction of trade costs in the Tripartite FTA, incomes of the poorest $40 \%$ of the populations in the EACU would increase by between $4.1 \%$ for Tanzania and $7.7 \%$ for Kenya. For COMESA and SADC, the poorest $40 \%$ of the population would see a significantly smaller increase in their incomes of 2.2 and $1.5 \%$, respectively. The smaller gains for the bottom $40 \%$ follow from the aggregate results: COMESA and SADC goods trade is primarily conducted (more than 97\%) with countries outside the Tripartite FTA. So, COMESA and SADC gain much less from NTB reduction and trade facilitation. The bottom $40 \%$ in SADC and especially COMESA, however, have a lot to gain from services liberalisation in the Tripartite area.

With unilateral liberalisation, incomes of the poorest $40 \%$ of the EACU populations would increase by a larger amount than from our Tripartite scenario: from $7.5 \%$ for Uganda to $9.8 \%$ for Rwanda.

\subsubsection{Inequality effects-decreased inequality with trade facilitation and increased inequality with services liberalisation}

For three of the four EACU countries we model in the Tripartite scenario (Tanzania excepted), the poorest $40 \%$ realise a larger increase in their incomes than the average of the entire population. The primary reason for these results is that the poor depend disproportionately on the earnings of unskilled labour. In the Tripartite scenario, trade facilitation is the reform responsible for the largest gains. Given our sector-specific dataset on trade facilitation, the trade facilitation scenario tends to favour agriculture, which is typically one of the most intensive users of unskilled labour. In the cases of Rwanda and Uganda, unskilled labour constitutes 70 and $74 \%$ of value added in our dataset and are among the most unskilled labour-intensive sectors. So, the expansion of agriculture drives up the relative wage of unskilled labour, yielding a reduction in inequality.

Although unilateral liberalisation by the EACU raises incomes of the bottom $40 \%$ more than in the Tripartite scenario, the Tripartite scenario would promote more equitable 
Table 4: Results for Poverty Headcount and Percentage, Income Distribution, and Average Welfare From Deep Integration Within the Tripartite FTA, the East Africa Customs Union (EACU) and Unilateral Reforms by the EACU

\begin{tabular}{|c|c|c|c|c|c|c|c|c|c|c|c|c|}
\hline Scenario definition & $\begin{array}{l}\text { Business as } \\
\text { usual: only } \\
\text { labour and } \\
\text { capital } \\
\text { expansion }\end{array}$ & $\begin{array}{l}\text { EACU central: } \\
\text { trade facilitation } \\
\text { plus services and } \\
\text { NTB } \\
\text { liberalisation }\end{array}$ & $\begin{array}{l}\text { EACU: only } \\
\text { trade } \\
\text { facilitation** }\end{array}$ & $\begin{array}{l}\text { EACU: only } \\
\text { services } \\
\text { liberalisation }\end{array}$ & $\begin{array}{l}\text { EACU: only } \\
\text { NTB } \\
\text { liberalisation }\end{array}$ & $\begin{array}{l}\text { EACU liberal: trade } \\
\text { facilitation plus } \\
\text { unilateral services } \\
\text { and NTM refrom } \\
\text { within EACU }\end{array}$ & $\begin{array}{l}\text { EACU } \\
\text { liberal: only } \\
\text { services } \\
\text { liberalisation }\end{array}$ & $\begin{array}{l}\text { EACU } \\
\text { Liberal: only } \\
\text { NTB } \\
\text { liberalisation }\end{array}$ & $\begin{array}{l}\text { Tripartite central: } \\
\text { trade facilitation } \\
\text { plus services and } \\
\text { NTB } \\
\text { liberalisation }\end{array}$ & $\begin{array}{l}\text { Tripartite: } \\
\text { only trade } \\
\text { facilitation }\end{array}$ & $\begin{array}{l}\text { Tripartite: } \\
\text { only services } \\
\text { liberalisation }\end{array}$ & $\begin{array}{l}\text { Tripartite: } \\
\text { only NTB } \\
\text { liberalisation }\end{array}$ \\
\hline Time in trade costs: & No & Yes & Yes & No & No & Yes & No & No & Yes & Yes & No & No \\
\hline \multicolumn{13}{|c|}{$20 \%$ reduction within EACU (Tripartite) countries* } \\
\hline Time in trade costs: & No & Yes & Yes & No & No & Yes & No & No & Yes & Yes & No & No \\
\hline \multicolumn{13}{|c|}{$5 \%$ reduction with non-EACU (Tripartite) countries* } \\
\hline Services liberalisation: & No & Yes & No & Yes & No & Yes & Yes & No & Yes & No & Yes & No \\
\hline \multicolumn{13}{|c|}{$50 \%$ reduction of discriminatory barriers within EACU (Tripartite)* } \\
\hline Services liberalisation: & No & No & No & No & No & Yes & Yes & No & No & No & No & No \\
\hline \multicolumn{13}{|c|}{$50 \%$ multilateral reduction of discriminatory barriers by EACU } \\
\hline Non-tariff barriers: & No & Yes & No & No & Yes & Yes & No & Yes & Yes & No & No & Yes \\
\hline \multicolumn{13}{|c|}{$20 \%$ reduction of costs within EACU (Tripartite) countries* } \\
\hline Non-tariff barriers: & No & No & No & No & No & Yes & No & Yes & No & No & No & No \\
\hline $\begin{array}{l}\text { Tariff: } 100 \% \text { removal } \\
\text { within the Tripart }\end{array}$ & $\begin{array}{l}\text { No } \\
\text { te regions }\end{array}$ & No & No & No & No & No & No & No & No & No & No & No \\
\hline Scenario number & S.1 & S.2 & S. 3 & S.4 & S.5 & S.6 & S.7 & S. 8 & S.9 & S.10 & S.11 & S.12 \\
\hline \multicolumn{13}{|c|}{ Headcount (in S.1, \% of the populaiton living in poverty in 2030; all other scenarios, percentage point deviations from the S.1 scenario) } \\
\hline Kenya & 16.63 & -0.90 & -0.54 & -0.01 & -0.20 & -1.90 & -1.22 & -0.10 & -1.71 & -0.98 & -0.62 & -0.32 \\
\hline Tanzania & 20.79 & -0.76 & -0.15 & 0.00 & -0.04 & -2.16 & -0.70 & -1.76 & -1.58 & -1.00 & -0.02 & -0.12 \\
\hline Uganda & 14.73 & -1.28 & -1.10 & -0.03 & -0.04 & -2.64 & -1.79 & -0.03 & -2.12 & -1.76 & -0.13 & -0.17 \\
\hline Rwanda & 51.66 & -1.11 & -0.84 & -0.13 & -0.03 & -3.93 & -3.10 & -0.09 & -2.70 & -1.98 & -0.23 & -0.09 \\
\hline COMESA & 8.48 & 0.00 & 0.00 & 0.00 & 0.00 & 0.00 & 0.00 & 0.00 & -0.63 & -0.09 & -0.47 & 0.00 \\
\hline SADC & 40.92 & 0.00 & 0.00 & 0.00 & 0.00 & 0.00 & 0.00 & 0.00 & -0.50 & -0.31 & -0.15 & -0.02 \\
\hline \multicolumn{13}{|c|}{ Poverty, millions of people in poverty in 2030 in scenario S.1; all other scenarios, deviations from Business as Usual (S.1) scenario, in millions of people } \\
\hline Kenya & 10.98 & -0.60 & -0.36 & -0.01 & -0.13 & -1.26 & -0.81 & -0.06 & -1.13 & -0.64 & -0.41 & -0.21 \\
\hline
\end{tabular}




\begin{tabular}{|c|c|c|c|c|c|c|c|c|c|c|c|c|}
\hline Tanzania & 16.41 & -0.60 & -0.12 & 0.00 & -0.03 & -1.70 & -0.55 & -1.39 & -1.25 & -0.79 & -0.02 & -0.10 \\
\hline Uganda & 9.28 & -0.80 & -0.69 & -0.02 & -0.02 & -1.66 & -1.13 & -0.02 & -1.34 & -1.11 & -0.08 & -0.11 \\
\hline Rwanda & 9.14 & -0.20 & -0.15 & -0.02 & 0.00 & -0.69 & -0.55 & -0.02 & -0.48 & -0.35 & -0.04 & -0.02 \\
\hline COMESA & 21.58 & 0.00 & 0.00 & 0.00 & 0.00 & 0.00 & 0.00 & 0.00 & -1.60 & -0.23 & -1.18 & -0.01 \\
\hline SADC & 134.41 & 0.00 & -0.01 & 0.00 & 0.00 & -0.02 & 0.00 & -0.01 & -1.63 & -1.00 & -0.49 & -0.06 \\
\hline \multicolumn{13}{|c|}{ Percentage change in weighted average real value of per capita household income } \\
\hline Kenya & 45.40 & 3.78 & 2.23 & 0.23 & 0.90 & 8.30 & 5.38 & 0.47 & 7.46 & 3.72 & 2.31 & 1.02 \\
\hline Tanzania & 20.75 & 1.76 & 1.08 & 0.03 & 0.37 & 9.68 & 2.35 & 5.69 & 4.47 & 2.33 & 0.30 & 0.99 \\
\hline Uganda & 37.10 & 1.01 & 0.85 & 0.16 & 0.05 & 6.46 & 5.39 & 0.13 & 3.80 & 3.22 & 0.39 & 0.11 \\
\hline Rwanda & 17.39 & 2.15 & 1.62 & 0.32 & 0.07 & 11.11 & 8.40 & 0.22 & 3.37 & 2.28 & 0.48 & 0.17 \\
\hline COMESA & 20.87 & 0.00 & 0.00 & 0.00 & 0.00 & 0.00 & 0.00 & 0.00 & 2.39 & 0.32 & 1.90 & 0.04 \\
\hline SADC & 45.42 & 0.00 & 0.01 & 0.00 & 0.00 & 0.04 & 0.01 & 0.02 & 1.55 & 1.01 & 0.52 & 0.08 \\
\hline
\end{tabular}

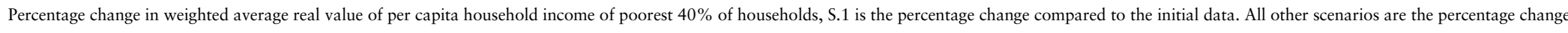
from the S.1 (BAU) scenario

\begin{tabular}{|c|c|c|c|c|c|c|c|c|c|c|c|c|}
\hline Kenya & 40.00 & 3.79 & 2.25 & 0.23 & 0.91 & 8.22 & 5.36 & 0.42 & 7.70 & 3.87 & 2.33 & 1.22 \\
\hline Tanzania & 16.53 & 1.80 & 1.07 & 0.03 & 0.35 & 8.95 & 1.72 & 5.10 & 4.08 & 2.35 & 0.30 & 0.98 \\
\hline Uganda & 25.01 & 2.79 & 2.38 & 0.15 & 0.17 & 7.54 & 4.80 & 0.13 & 5.67 & 4.56 & 0.34 & 0.41 \\
\hline Rwanda & 8.41 & 2.32 & 1.73 & 0.28 & 0.07 & 9.82 & 7.60 & 0.18 & 7.15 & 4.93 & 0.41 & 0.23 \\
\hline COMESA & 15.95 & 0.00 & -0.01 & 0.00 & 0.00 & 0.00 & 0.00 & 0.00 & 2.21 & 0.35 & 1.79 & 0.03 \\
\hline SADC & 44.06 & -0.01 & 0.00 & -0.07 & -0.01 & 0.03 & -0.01 & 0.01 & 1.51 & 0.89 & 0.42 & 0.06 \\
\hline
\end{tabular}

*Reductions apply to the EACU countries or the Tripartite countries depending on whether the scenario is EACU or Tripartite.

**:Trade facilitation within EACU is part of the 'EACU liberal' scenario also.

Source: Authors' estimates. 
growth in the EACU than unilateral liberalisation, especially for Rwanda and Uganda. The reason is that, with unilateral liberalisation, services expansion is the most important reform. The services sectors are the most intensive users of skilled labour, so their expansion drives up the relative wage of skilled labour, which tends to reduce the share of income of the bottom $40 \%$. We emphasise that services liberalisation has an important impact on poverty reduction and increasing incomes of the poorest $40 \%$ of the population; so, services liberalisation is a crucial tool in the fight to eliminate poverty. However, these results tend to suggest it has an adverse impact on the share of income going to the poorest $40 \%$.

\section{Conclusions}

Our poverty results suggest that the effects of the trade reforms to reduce trade costs are pro-poor. For example, we estimate that reduction of trade costs within the Tripartite agreement would reduce the number of poor in the whole region by 7.43 million; and the incomes of the poorest $40 \%$ of the population would increase by from $1.5 \%$ in the case of SADC to $7.7 \%$ in the case of Kenya. Focusing on poverty reduction in Kenya, Tanzania, Uganda, and Rwanda, unilateral expansion of the reforms to lower trade costs to the entire world would lift an additional 1.1 million out of poverty, compared with deep integration within the Tripartite FTA alone. This indicates that while deep regional integration is an important step in helping to reduce poverty, the region should not ignore the additional gains available from broader trade liberalisation.

de Melo and Tsikata (2015) have documented that conflicting perceptions of the gains from deeper integration in Africa has been an obstacle to progress. We hope that our results, that clarify the gains from the different reforms, can facilitate a negotiation that leads to mutual benefits We show that the reforms affect countries differently, which could lead to countries lobbying for different reforms as part of a strategy that maximises poverty reduction. This is typical in trade negotiations, as a country will often have to make 'concessions' in areas it is not highly motivated to reform, in order to obtain agreement from other countries on what is most important to it. For example, in the Tripartite scenario, the country that has the most to gain from services liberalisation is Kenya: in terms of percentage points of poverty reduction $(-0.62 \%)$ or incomes of the poorest $40 \%$ (increase of $2.31 \%$ ), Kenya has the most to gain from Tripartite services liberalisation. However, based on the percent living in poverty or the results for the poorest $40 \%$ of the households, Rwanda and Uganda have the most to gain from trade facilitation. Since all these reforms benefit all the countries, the 'exchange of concessions' would lead to a more desirable trade agreement.

We find that trade facilitation tends to both increase incomes of the poor as well as reduce inequality. The latter is due to the disproportional gains in agriculture that tends to benefit unskilled labour. Services liberalisation is also strongly pro-poor as it reduces poverty and raises incomes of the poorest $40 \%$ of the population. Nonetheless, it tends to increase wages of skilled workers more than unskilled workers, and thereby increase inequality. Finally, BTY (2015b) estimate that adjustment costs are only a small percentage of the gains from trade liberalisation in Eastern and Southern Africa. Nonetheless, the poor are often very badly equipped to handle adjustment costs. This highlights the value of effective safety net programmes that may assist the poor through the transition. 


\section{References}

Anderson K., Martin W., van der Mensbrugghe D. (2006) 'Would Multilateral Trade Reform Benefit Sub-Saharan Africans?', Journal of African Economies, 15 (4): 626-70.

Arvis J.-F., Duval Y., Shepherd B., Tuatha C., Raj A. (2016) 'Trade Costs in the Developing World: 1996-2010', World Trade Review, Vol. 15 (3): 451-74.

Baldwin R. E., Forslid R., Haaland J. (1999) 'Investment creation and investment diversion: simulation analysis of the single market programme', in Baldwin R., Francois J. (eds), Dynamic Issues in Applied Commercial Policy Analysis. Cambridge: Cambridge University Press.

Balistreri E. J., Jensen J., Tarr D. G. (2015a) 'What Determines Whether Preferential Liberalization of Barriers against Foreign Investors in Services are Beneficial or Immizerising: Application to the case of Kenya', Economics: The Open-Access, Open-Assessment E-Journal, 9 (2015-42): 1-134. http://dx.doi.org/10.5018/economics-ejournal.ja.2015-42.

Balistreri E. J., Maliszewska M., Osorio-Rodarte I., Tarr D. G., Yonezawa H. (2016) 'Poverty and Shared Prosperity Implications of Deep Integration in Eastern and Southern Africa,' World Bank Policy and Research Working Paper No. 7660, May, http://documents. worldbank.org/curated/en/905551468180262500/Poverty-and-shared-prosperity-implicationsof-deep-integration-in-Eastern-and-Southern-Africa. Accessed August 15, 2015.

Balistreri E. J., Rutherford T. F., Tarr D. G. (2009) 'Modeling Services Liberalization: The Case of Kenya', Economic Modeling, 26 (3): 668-79.

Balistreri E. J., Tarr D. G., Yonezawa H. (2015b) 'Deep Integration in East and Southern Africa: What are the Stakes?', Journal of African Economies, Vol. 24 (5): 677-706.

Balistreri E. J., Tarr D. G., Yonezawa H. (2014) 'Reducing Trade Costs in East Africa: Deep Regional Integration and Multilateral Action,' World Bank Policy and Research Working Paper No. 7049, September, http://papers.ssrn.com/sol3/papers.cfm?abstract_id=2503724. Accessed August 15, 2015.

Borchert I., Gootiiz B., Mattoo A. (2014) 'Policy Barriers to International Trade in Services: Evidence from a New Database', World Bank Economic Review, 28: 162-88.

Boysen O., Matthews A. (2016) 'Will Economic Partnership Agreements increase poverty? The case of Uganda', Review of Development Economics. DOI:10.1111/rode.12272.

Bourguignon F., Bussolo M. (2013) 'Income distribution in computable general equilibrium modeling', in Dixon P. B., Jorgenson D. (eds), Handbook of Computable General Equilibrium Modeling, Vol. 1. Amsterdam: Elsevier, pp. 1383-1437.

Bourguignon F., Ferreira F., Leite P. (2008) 'Beyond Oaxaca-Blinder: Accounting for Differences in Household Income Distributions Across Countries', Journal of Economic Inequality, 6 (2): $117-48$.

Brenton P., Isik G. (2012) De-fragmenting Africa: Deepening Regional Trade Integration in Goods and Services. Washington DC: The World Bank.

Bussolo M., De Hoyos R. E., Medvedev D. (2010) 'Economic Growth and Income Distribution: Linking Macroeconomic Models with Household Survey Data at the Global Level', International Journal of Microsimulation, Vol. 3 (1): 92-103.

Bussolo M., Lay J., Medvedev D., van der Mensbrugghe D. (2008) 'Trade options for Latin America: a poverty assessment using a top-down macro-micro modeling framework', in Bourguignon B., da Silva P. (eds), The Impact of Macroeconomic Policies on Poverty and Income Distribution. New York: Palgrave MacMillan and the World Bank, pp. 61-92.

Bussolo M., Niimi Y. (2009) 'Do Regional Trade Agreements Benefit the Poor? An Illustration from Dominican Republic-Central American Free Trade Agreement in Nicaragua', World Development, 17 (1): 146-60.

Cadot O., Gourdon J. (2014) 'Assessing the Price-Raising Effect of Non-Tariff Measures in Africa', Journal of African Economies, Vol. 23 (4): 425-63. 
Caliendo L., Feenstra R. C., Romalis J., Taylor A. M. (2015) 'Tariff Reductions, Entry and Welfare: Theory and Evidence for the Last Two Decades,' NBER Working Paper, No. 2178.

Caliendo L., Parro F. (2015) 'Estimates of the Trade and Welfare Effects of NAFTA', Review of Economic Studies, 82 (1): 1-44. https://doi.org/10.1093/restud/rdu035.

Costinot A., Rodriguez-Clare A. (2014) 'Trade theory with numbers: quantifying the consequences of globalization', in Helpman E., Rogoff K., Gopinath G. (eds), Handbook of International Economics, vol. 4. Amsterdam: Elsevier, pp. 197-262.

Davies J. (2009) 'Combining Microsimulation with CGE and Macro Modelling for Distributional Analysis in Developing and Transition Countries', The International Journal of Microsimulation, 2 (1): 49-65.

de Melo J., Tsikata Y. (2015) 'Chapter 10-Regional integration in Africa: challenges and prospects', in Monga C., Lin J. (eds), The Oxford Handbook of Africa and Economics: Volume 2, Policies and Practices. Oxford: Oxford University Press.

de Melo J., Vijil M. (2016) 'The Critical Mass Approach to Achieve a Deal on Green Goods and Services: What is on the Table? How Much to Expect?', Environment and Resource Economics, 21 (3): 393-414.

Devarajan S., Go D. S., Maliszewska M., Osorio-Rodarte I., Timmer H. (2015) 'Stress-Testing Africa's Recent Growth and Poverty Performance', Journal of Policy Modeling, 37 (4): 521-47.

East African Community Secretariat (2011) 'East African Transport Strategy and Regional Road Sector Development Program and East African Trade and Transport Facilitation Project,' September.

East African Community (2012) 'Status of Elimination of Non-Tariff Barriers in the East African Community,' Vol. 5, December.

Fontagné L., Mitaritonna C., Signoret J. (2016) 'Estimated Tariff Equivalents of Services NTMs,' CEPII Working Paper No. 2016-20, August.

Francois J., Hoekman B. (2010) 'Services Trade and Policy', Journal of Economic Literature, 642-92.

Francois J., Hoekman B., Woerz J. (2007) 'Does Gravity Apply to Nontangibles? Estimates of Trade and FDI Openness in Services,' mimeo, https://www.gtap.agecon.purdue.edu/resources/ download/3407.pdf. Accessed August 15, 2015.

Francois J., Manchin M., Norberg H., Pindyuk O., Tomberger P. (2013) 'Reducing Transatlantic Barriers to Trade and Investment: An Economic Assessment,' Prepared under European Commission implementing Framework Contract TRADE10/A2/A16, http://trade.ec.europa.eu/ doclib/docs/2013/march/tradoc_150737.pdf. Accessed August 15, 2015.

Francois J., McDonald B., Nordstom H. (1996) 'Assessing the uruguay round', in Martin Will, Winters L. Alan (eds), The Uruguay Round and the Developing Countries. Cambridge: Cambridge University Press.

Fukui T., Lakatos C. (2012) 'A Global Database of Foreign Affiliate Sales', GTAP Research Memorandum No, July: 24.

Harrison G. H., Rutherford T. F., Tarr D. (1996) 'Increased Competition and Completion of the Market in the European Community: Static and Steady-State Effects', Journal of Economic Integration, 11 (3): 332-365. September 1996.

Harrison G. H., Rutherford T. F., Tarr D. (1997a) 'Economic Implications for Turkey of a Customs Union with the European Union', European Economic Review, 41 (3-5): 861-70.

Harrison G., Rutherford T., Tarr D. (1997b) 'Quantifying the Uruguay Round', Economic Journal, 107 (444): 1405-30.

Harrison G. H., Rutherford T. F., Tarr D. (2002) 'Trade Policy Options for Chile: The Importance of Market Access', World Bank Economic Review, 16 (1): 49-79. 
Hummels D. L., Schaur G. (2013) ‘Time as a Trade Barrier’, American Economic Review, 103: $1-27$.

Hummels D. L., Minor P., Reisman M., Endean E. (2007) Calculating tariff equivalents for time in trade. Arlington, VA: Nathan Associates Inc for the United States Agency for International Development (USAID).

Jafari Y., Tarr D. G. (2015) 'Estimates of the Ad Valorem Equivalents of Foreign Discriminatory Regulatory Barriers in 11 Services Sectors for 103 countries', The World Economy, Vol. 40 (3): 544-73. DOI:10.1111/twec.12329.

Jensen H. G., Sandrey R. (2011) 'The Tripartite Free Trade Agreement: A Computer Analysis of the Impacts,' Tralac Working Paper No. N11WP06/2011, March.

Jensen J., Rutherford T., Tarr D. (2010) 'Modeling Services Liberalization: The Case of Tanzania', Journal of Economic Integration, 25 (4): 644-75.

Jensen J., Tarr D. G. (2012) 'Deep Trade Policy Options for Armenia: The Importance of Trade Facilitation, Services and Standards Liberalization', Economics: The Open Access-Open Assessment E-Journal, 6: 2012-1. http://dx.doi.org/10.5018/economics-ejournal.ja.2012-1.

Karingi S., Fekadu B. (2009) 'Beyond Political Rhetoric-the Meaning of the Grand Eastern and Southern Africa FTA,' UN Economic Commission for Africa, April.

Kee H. L., Nicita A., Olarreaga M. (2009) 'Estimating Trade Restrictiveness Indices', Economic Journal, 119: 172-99.

Kimura F., Lee H. (2004) 'The Gravity Equation in International Trade in Services,' Paper Presented at the European Trade Study Group Conference, September 9-11, Nottingham.

Latorre M. C. (2016) 'A CGE Analysis of the Impact of Foreign Direct Investment and Tariff Reform on Female and Male Workers in Tanzania', World Development, 77: 346-66.

Limão N. (2016) 'Preferential trade agreements', in Bagwell K., Staiger R. W. (eds), Handbook of Commercial Policy. Amsterdam: North-Holland.

Maliszewska M., Orlova I., Taran S. (2009) 'Deep Integration with the EU and its Likely Impact on Selected ENP Countries and Russia,' Case Network Report No. 88/2009, http://papers. ssrn.com/sol3/papers.cfm?abstract_id=1518342. Accessed August 15, 2017.

Mevel S., Karingi S. (2012) 'Deepening Regional Integration in Africa: A Computable General Equilibrium Assessment of the Establishment of a Continental Free Trade Area followed by a Continental Customs Union,' Paper presented at the 7th African Economic Conference, Kigali, Rwanda, 30 October-2 November.

Minor P. (2013) 'Time as a Barrier to Trade: A GTAP Database of Ad Valorem Trade Time Costs,' ImpactEcon, Second Edition, October, http://mygtap.org/resources/.

Montenegro C. E., Hirn M. L. (2009) 'A New Disaggregated Set of Labor Market Indicators Using Standardized Household Surveys from Around the World,' World Development Report Background Paper, https://openknowledge.worldbank.org/bitstream/handle/10986/9033/ WDR2009_0015.pdf

Pearson M. (2012) 'Trade facilitation in the COMESA-EAC-SADC tripartite free trade area,'in Hartzenberg T. and others (eds), The Tripartite Free Trade Area: Towards a New African Integration Paradigm. Stellenbosch, South Africa: Trade Law Centre for Southern Africa.

Rutherford T. F., Tarr D. (2008) 'Poverty Effects of Russian WTO Accession: Modeling 'Real' Households With Endogenous Productivity Effects', Journal of International Economics, 75 (1): 131-50.

Schiff M., Winters L. A. (2003) Regional Integration and Development. Oxford: Oxford University Press and the World Bank.

Teichman I. (2016) 'CGE-Based Methods to Measure the Impact of Trade Liberalization on Poverty,' DIW Roundup, July 28, 1-12, http://www.diw.de/sixcms/detail.php?id=diw_01.c. 540414.de. Accessed August 15, 2017. 
United Nations Department of Economic and Social Affairs Population Division. (2015) World Population Prospects: The 2015 Revision, http://esa.un.org/unpd/wpp/DVD/. Accessed August $15,2017$.

Willenbockel D. (2013) 'General Equilibrium Analysis of the COMESA-EAC-SADC Tripartite FTA, Draft Final Report to TradeMark Southern Africa,' August 2013.

Wittenberg M. (2010) 'An Introduction to Maximum Entropy and Minimum Cross-Entropy Estimation Using Sta', The Stata Journal, 10 (3): 315-30.

Wonnacott P., Wonnacott R. (1981) 'Is Unilateral Tariff Reduction Preferable to a Customs Union? The Curious Case of the Missing Foreign Tariffs', American Economic Review, Vol. 71 (4): 704-14.

World Bank (2012) East African Community: Reshaping Economic Geography of East Africa: From Regional to Global Integration, Report No. 6599-AFR, Poverty Reduction and Economic Management Unit, Africa Region, June.

World Economic Forum (2012) The Global Enabling Trade Report, 2012: Reducing Supply Chain Barriers, edited by Robert Lawrence, Margareta Drzeniek Hanouz and Sean Doherty, http://www3.weforum.org/docs/GETR/2012/GlobalEnablingTrade_Report.pdf. Accessed August $15,2017$.

Yotov Y. V. (2012) 'A Simple Solution to the Distance Puzzle in International Trade', Economic Letters, 117: 794-8. 